\title{
Papan Jam Analog: Media Edukatif Pembelajaran Matematika Madrasah Ibtidaiyah
}

\author{
Linda Indiyarti Putri ${ }^{1, \text { a) }}$, Abdul Basir ${ }^{1}$ \\ ${ }^{1}$ Universitas Wahid Hasyim \\ Jl. Menoreh Selatan X No. 22 Sampangan, Gajah Mungkur, Semarang, Indonesia, 50236 \\ a)lindaputri5@gmail.com
}

\begin{abstract}
The students' difficulties on understanding the material and the lack of the enthusiasm in learning mathematics, especially in angle measurement material were be the basic reasons for this research. In addition, conventional learning methods that characterized by lectures were still often used by teachers in learning. Therefore, the learning not being more active, effective, and enjoyable. The development of educational learning media like analog clock board was one of the solutions to improve students' understanding. This research aims to determine the effectiveness of analog clock board as learning media to solve mathematics learning problems. The development model used was a 4D development research model. The results of media validation stated that analog clock board was feasible to be used in mathematics learning for angle measurement material. In addition, the results of the questionnaire shown that $90 \%$ of teachers and $100 \%$ of students stated the media was "very interested". The experiment results showed that analog clock board was more effective to improve students' understanding on angle measurement.
\end{abstract}

Keywords: analog clock board; angle measurements; learning media

\begin{abstract}
Abstrak. Kesulitan dalam memahami materi dan kurangnya antusiasme siswa dalam belajar matematika terutama pada materi pengukuran sudut menjadi alasan dasar penelitian ini dilakukan. Selain itu, metode belajar konvensional yang ditandai dengan ceramah masih sering digunakan guru dalam pembelajaran. Hal ini menyebabkan pembelajaran kurang aktif, dan efektif, dan menyenangkan. Pengembangan media pembelajaran edukatif papan jam analog menjadi salah satu solusi dalam meningkatkan pemahaman siswa terhadap materi. Penelitian ini bertujuan mengetahui efektifitas penggunaan media pembelajaran papan jam analog untuk memecahkan permasalahan pembelajaran matematika. Model pengembangan yang digunakan adalah model penelitian pengembangan 4D. Hasil validasi menyatakan bahwa papan jam analog layak untuk digunakan pada pembelajaran matematika materi pengukuran sudut. Hasil penyebaran angket menunjukkan bahwa $90 \%$ guru dan $100 \%$ peserta didik menyatakan "sangat tertarik" pada media yang dikembangkan. Hasil uji coba media menunjukkan bahwa penggunaan media edukatif papan jam analog lebih efektif dalam meningkatkan pemahaman siswa terhadap materi pengukuran sudut.
\end{abstract}

Kata Kunci: media belajar; papan jam analog; pengukuran sudut 


\section{PENDAHULUAN}

Pada prinsipnya, pembelajaran merupakan sebuah sistem yang terdiri dari input, proses, dan output. Proses menjadi salah satu poin penting dalam sebuah pembelajaran karena turut menentukan tercapainya tujuan pembelajaran. Ketercapaian sebuah proses pembelajaran ditandai dengan adanya perubahan tingkah laku baik secara pengetahuan (kognitif), keterampilan (psikomotor), maupun dalam nilai dan sikap (afektif) (Andrianto, 2017). Seiring perkembangan zaman, proses pembelajaran tidak lagi berpatokan dengan adanya sumber belajar, tempat dan waktu, akan tetapi media penunjang seperti media software maupun hardware dibutuhkan oleh peserta didik (Andrianto, 2017).

Dalam proses pengembangan pengetahuan, beberapa tokoh kontruktivisme seperti Dewey, Piaget, dan Montessori mempunyai pandangan senada yang menyatakan bahwa pembentukan pengetahuan anak "dibebaskan" aktif menciptakan struktur-struktur kognitif dalam interaksinya dengan lingkungan. Penekanan belajar peserta didik secara aktif dan mandiri inilah yang perlu dikembangkan (Nugrahanta, Rismiati, Anugrahana, \& Kurniastuti, 2016). Untuk itu dibutuhkan sebuah lingkungan yang mampu memfasilitasi kebutuhan anak dalam mengembangkan proses kognisinya secara mandiri. Pengetahuan (knowledge) dibentuk dari segala sesuatu yang terkait dengan pengalaman sehari-hari seseorang yang disebut dengan istilah common-sense knowing, yang kemudian mampu memberikan sebuah pemahaman (understanding) (Setyosari, 2016).

Pada umumnya anak usia delapan sampai sebelas tahun sudah dapat berpikir secara konkret tentang permasalahan-permasalahan matematika yang diberikan. Pada usia ini anak akan mulai secara bertahap untuk membangun pola pikir mereka secara abstrak (Ahdianto, 2016). Untuk membangun pola pikir anak menuju hal yang abstrak membutuhkan perlakuan yang tepat. Penalaran dan koneksi matematis penting untuk diketahui pada saat peserta didik mengerjakan matematika (doing math) (Junaedi \& Asikin, 2012). Media sebagai penunjang pembelajaran berfungsi sebagai jembatan penghubung untuk mengembangkan keterampilan berpikir pada mata pelajaran yang syarat dengan konten-konten abstrak (Putra, Ulandari \& Sepnila, 2020). Beberapa penelitian pengembangan dapat menghasilkan produk, konsep, alat, metode, program, atau cara yang dapat mempermudah dalam mengatasi permasalahan pembelajaran yang dihadapi (Prasetyo, 2015; Lukman \& Setiani, 2018).

Hal yang tidak kalah penting sebagai pengaruh pembelajaran berbasis media adalah menumbuhkan jiwa kemandirian dalam usaha mengeksplorasi pengetahuan baru yang diterima oleh peserta didik (Betyka, Putra \& Erita, 2019). Menghadapi kondisi tersebut, diperlukan sebuah solusi alternatif yang mampu menjadikan pembelajaran matematika menjadi lebih humanistik, menyenangkan, dan mengedepankan kreativitas peserta didik. Pembelajaran yang tidak hanya 
berkutat pada aspek kognitif, melainkan lebih mengedepankan pada internalisasi nilai-nilai sebagai upaya membentuk kecerdasan dan kepribadian sosial peserta didik.

Pengukuran sudut merupakan salah satu cabang dalam bidang ilmu matematika yang mempelajari tentang geometri. Pada dasarnya pengukuran sudut dapat dilakukan dengan cara yang mirip dalam mengukur atribut lainnya, seperti panjang. Pengukuran sudut merupakan salah satu materi dari mata pelajaran matematika di kelas IV Sekolah Dasar (SD). Menurut (Widyawati, Putri, \& Somakim, 2016), sudut memiliki manfaat dalam kehidupan sehari-hari yaitu untuk menghitung tinggi benda, sebagai bidang miring untuk memudahkan pekerjaan, dan sudut digunakan dalam keindahan dan kekuatan pada bangunan (Mariyana, Rosady, \& Latifah, 2018).

Beberapa riset-riset terkait upaya meningkatkan kualitas pembelajaran matematika menggunakan berbagai media pembelajaran telah terbukti memberikan hasil yang signifikan terhadap peningkatan hasil belajar. Diantaranya produk pengembangan tersebut berupa pengembangan alat peraga edukatif Misbilbul (Mistar Bilangan Bulat) untuk pemahaman materi bilangan bulat kelas IV (Andrianto, 2017). Selain itu, kajian pengembangan alat peraga peraga garis satuan panjang pada peserta didik kelas IV SD Negeri I Kutoarjo menunjukkan bahwa persentase ketuntasan hasil belajar klasikal sebesar $86,8 \%$ lebih besar dari nilai ketuntasan yang ditetapkan yaitu 75\% (Nurmutiatun, 2018). Selanjutnya penelitian tentang pengembangan media pembelajaran android apps berbasis discovery learning yang layak digunakan dan dapat meningkatkan pemahaman konsep matematis (Ariyanto, Aditya, \& Dwijayanti, 2019). Kesadaran akan dibutuhkannya media belajar pada pembelajaran matematika terlihat juga pada hasil penelitian yang mengembangkan media belajar operasi hitung bagi jenjang Sekolah Dasar (Malasari \& Hakim, 2017).

Penggunaan media belajar seperti alat peraga akan lebih mendekatkan peserta didik dengan pengalaman sehari-hari tentang konsep-konsep secara matematis realistis. Pembelajaran yang menggunakan pendekatan pengalaman dengan berbagai situasi dalam dunia nyata (realistik) akan lebih bermakna. Hal ini terbukti dari hasil penelitian yang menunjukkan bahwa penggunaaan konteks Rumah Limas dapat mendukung peserta didik memahami materi sudut sebagai bentuk pembelajaran berbasis realistik (Widyawati et al., 2016). Salah satu riset pengabdian tentang pengembangan alat peraga matematika untuk meningkatkan motivasi dan hasil belajar menunjukkan bahwa penggunaan alat peraga matematika mendapatkan respon positif dari peserta dan guru (Murdiyanto \& Mahatama, 2014). Beberapa hasil penelitian tersebut menguatkan penelitian ini dilakukan mengingat bahwa peserta didik kelas IV Madrasah Ibtida'iyah Nashrul Fajar Semarang kemampuan dalam memahami pengukuran sudut masih belum optimal. Penelitian ini dimaksudkan untuk memberikan sumbangan yang berguna untuk mengembangkan produk alat 
peraga dan melakukan serangkaian uji coba untuk mengetahui efektivitas media edukatif papan jam analog di kelas IV Madrasah Ibtida'iyah Nashrul Fajar Semarang.

\section{METODE PENELITIAN}

Jenis penelitian ini merupakan field research dengan menggunakan pendekatan penelitian dan pengembangan yang biasa dikenal dengan istilah Research and Development $(R \& D)$. Model pengembangan yang digunakan adalah 4-D dengan mengikuti alur dari Sivasailam Thiagarajan, Dorothy S. Semmel, dan Melvyn I. Semmel. Tahapan dari Model pengembangan 4D adalah define, design, develop, dan disseminate atau diadaptasikan menjadi model 4P yaitu pendefinisian, perancangan, pengembangan, dan penyebaran (Trianto, 2010).

Pada tahap define, peneliti mengidentifikasi masalah (problems identify) dengan cara mewawacarai salah satu peserta didik Madrasah Ibtida'iyah Nashrul Fajar Semarang dan diperoleh informasi bahwa belum terdapat media alat peraga edukatif papan jam analog yang digunakan pada pembelajaran materi pengukuran sudut. Selain itu, peneliti juga menganalisis latar (setting analyze) yaitu pengumpulan data tentang karakteristik sasaran. Hasil wawancara guru menunjukkan bahwa (1) peserta didik cenderung mudah bosan, (2) guru membutuhkan alat peraga dalam penyampaian materi pembelajaran, (3) peserta didik sulit memahami konsep perhitungan sudut, dan (4) masih terbatasnya media pembalajaran yang digunakan. Pada tahap design, peneliti melakukan lima tahapan (Sugiyono, 2017). Pertama, analisis potensi dan masalah berdasatkan informasi yang diperoleh pada tahap sebelumnya. Kedua, perumusan tujuan pengembangan produk. Ketiga, pengembangan ide, termasuk masukan dari pembimbing. Keempat, penyaringan ide. Kelima pengevaluasian ide, pada tahap ini peneliti meminta masukan dari pembimbing. Keenam pertimbangan konsumen dengan cara meminta pendapat dari guru matematika di MI Ibtida'iyah Nashrul Fajar Semarang. Ketujuh, desain produk kasar atau permulaan. Papan jam analog yang dikembangkan dalam penelitian ini dapat dilihat pada Gambar 1.

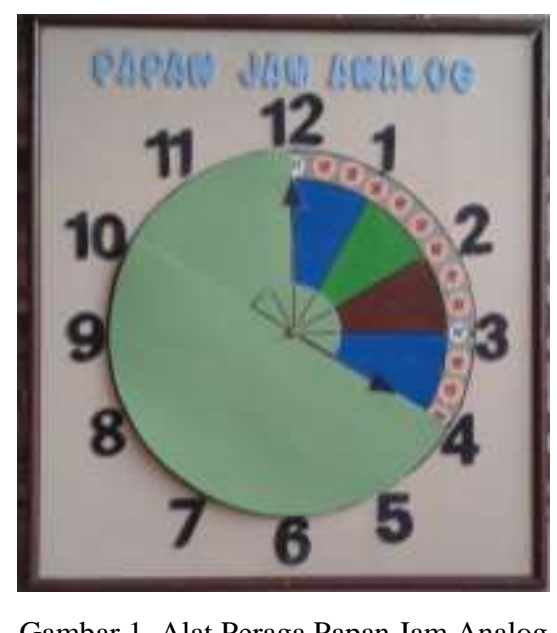


Pada tahap develop dilakukan expert appraisal, yaitu validasi kelayakan rancangan produk yang dilakukan oleh ahli media dan ahli materi dan ditinjau oleh guru kelas IV. Tahap validasi diperlukan untuk mengetahui kelebihan dan kelemahan dari alat peraga papan jam analog, serta mengetahui apa saja yang perlu ditambahkan pada desain sebelum diujikan. Selain itu juga dilakukan developmental testing, yaitu kegiatan uji coba rancangan produk pada sasaran subjek yang sesungguhnya. Dalam proses kegiatan uji coba, terdapat tiga kali ujicoba, yaitu ujicoba perorangan, kelompok kecil, dan uji coba kelompok besar. Langkah awal dalam uji coba produk kepada peserta didik adalah dengan membagikan alat peraga dengan tema perhitungan sudut kepada kelas kontrol yang terdiri dari 31 peserta didik dan kelas eksperimen berisi 25 peserta didik. Setelah itu dilakukan penyebaran angket respon peserta didik terhadap praktikalitas penggunaan alat peraga jam analog dengan tema perhitungan sudut. Pada tahap berikutnya, dissemination, produk diberikan kepada Madrasah Ibtida'iyah Nashrul Fajar Semarang agar memiliki nilai guna dan kebermanfaatan baik dalam konteks empiris di lapangan maupun sebagai bahan kajian akademik untuk penelitian berikutnya.

Masing-masing tahapan dijabarkan sesuai dengan kebutuhan perolehan data hingga kesiapan produk yang dihasilkan. Alur desain penelitian pengembangan model 4D (Four D Models) menurut Thiagarajan dapat dilihat pada Gambar 2.

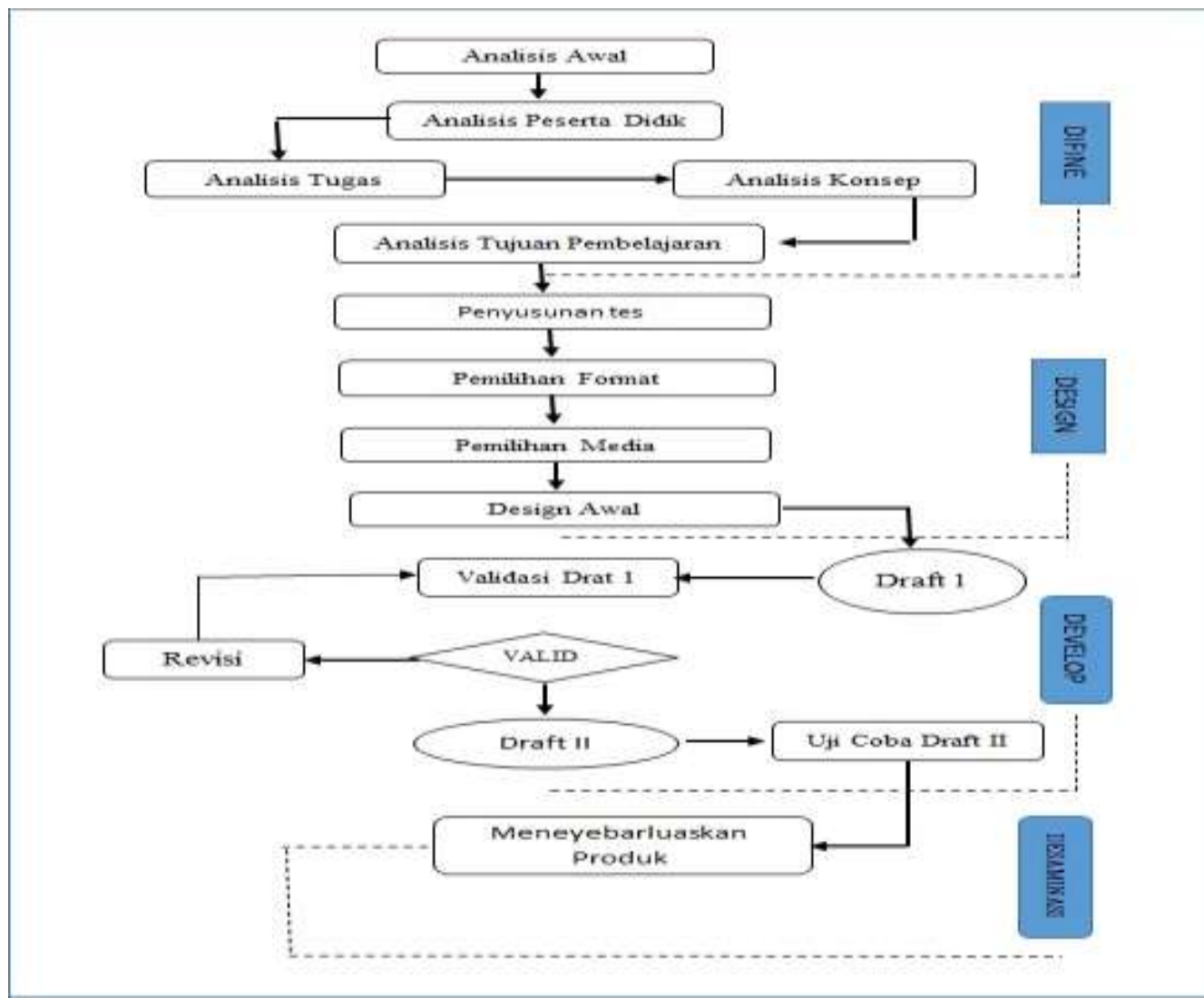

Gambar 2. Prosedur Pengembangan Model 4D (Diadaptasi dari Thiagarajan) 
EDUMATIKA: Jurnal Riset Pendidikan Matematika

e-ISSN 2620-8911

Volume 3, Nomor 1, Mei 2020

p-ISSN 2620-8903

Pada tahap implementasi, produk yang telah diuji coba diterapkan dalam situasi nyata dengan pembelajaran yang sesungguhnya. Setelah pembelajaran dilaksanakan, diberikan angket persepsi kepada peserta didik yang merupakan angket tertutup untuk menilai aspek pada media secara keseluruhan. Selain itu, pada tahap ini juga digunakan soal post-test. Evaluasi dilakukan pada setiap tahap pengembangan untuk memperbaiki media pada tiap tahap atau disebut evaluasi formatif. Sehingga diperoleh produk yang layak untuk digunakan pada proses pembelajaran.

Jenis data yang diambil yaitu data kualitatif dan data kuantitatif. Metode pengumpulan data yang digunakan dalam penelitan adalah metode observasi, wawancara, dan angket. Data kualitatif diperoleh dari hasil validator ahli media, ahli materi, tanggapan dari guru kelas IV, dan hasil angket persepsi peserta didik terhadap media pembelajaran yang telah dibuat. Sedangkan kuantitatif diperoleh dari hasil belajar peserta didik melalui post-test (tes akhir) dan respon dari guru dan peserta didik. Dalam penelitian ini, instrumen yang digunakan adalah berupa angket dan soal posttest.

Penelitian ini berdesain posttest- only control desain yaitu desain penelitian dalam pengujian rumus hipotesis yaitu menggunakan nilai post-test (Sugiyono, 2016). Adapun rancangan yang digunakan dapat dilihat pada Tabel 1 .

Tabel 1. Prosedur Penelitian

\begin{tabular}{ccc}
\hline Kelas & Perlakuan & Test \\
\hline Kelas Eksperimen & Menggunakan alat peraga & Post-Test \\
\hline Kelas Kontrol & Metode konvensional & Post-Test \\
\hline
\end{tabular}

Pada Tabel 1 terlihat bahwa kelas kontrol digunakan sebagai pembanding. Pada kelas eksperimen digunakan alat peraga papan jam analog pada materi pengukuran sudut. Setelah mendapatkan perlakuan yang berbeda pada masing-masing kelas, pada kedua kelas diberikan tes dengan materi yang sama untuk mengetahui perbandingan prestasi belajar keduanya. Dengan menggunakan analisis statistik, perbedaan dua sampel berpasangan antara kelas kontrol dan eksperimen pada post-test dapat dianalisis menggunakan uji t-test (Sugiyono, 2017).

\section{HASIL DAN PEMBAHASAN}

\section{Validasi oleh Pakar}

Proses validasi alat peraga dilakukan dengan cara memberikan angket kepada 2 orang ahli yang masing-masing merupakan ahli media akan menilai dari segi teknis dan kualitas produk pembelajaran dan ahli materi memberikan penilaian mengenai kualitas media dari aspek materi pengukuran sudut. Hasil validasi oleh tim ahli disajikan dalam Tabel 2. 
EDUMATIKA: Jurnal Riset Pendidikan Matematika

Tabel 2. Hasil Validasi Tim Ahli

\begin{tabular}{cccccc}
\hline No. & Indikator & Jumlah skor & $\begin{array}{c}\text { Total } \\
\text { skor }\end{array}$ & Persentase & Kategori \\
\hline A & Aspek Media & & & & \\
\hline 1. & Kesesuaian & 21 & 25 & $84 \%$ & Valid \\
\hline 2. & Kelayakan & 30 & 35 & $86 \%$ & Valid \\
\hline 3. & Keakuratan & 13 & 15 & $87 \%$ & Valid \\
\hline 4. & Tampilan & 23 & 25 & $92 \%$ & Valid \\
\hline & Jumlah & 87 & 100 & $87 \%$ & Valid \\
\hline B & Aspek Materi & & & & \\
\hline 1. & Kesesuaian Materi & 20 & 25 & $80 \%$ & Valid \\
\hline 2. & Kelayakan Materi & 16 & 20 & $80 \%$ & Valid \\
\hline 3. & Penyajian Materi & 22 & 30 & $67 \%$ & Valid \\
\hline 4. & Kompetensi Materi & 20 & 25 & $80 \%$ & Valid \\
\hline & Jumlah & 78 & 100 & $78 \%$ & Valid \\
\hline
\end{tabular}

Dari hasil validasi dapat disimpulkan bahwa semua indikator kelayakan produk alat peraga dinilai valid sehingga layak digunakan dalam pembelajaran.

\section{Respon Guru dan Peserta Didik}

Setelah dilaksanakan uji coba produk, diberikan angket kepada guru kelas IV untuk menilai praktikalitas penggunaan alat peraga papan jam analog. Respon guru sangat baik sebagaimana terihat pada Tabel 3 .

Tabel 3. Rekap Tanggapan Guru terhadap Alat Peraga Papan Jam Analog

\begin{tabular}{|c|c|c|c|c|c|c|c|}
\hline \multirow{2}{*}{ No. } & \multirow{2}{*}{ Aspek yang dinilai } & \multicolumn{4}{|c|}{ Jumlah Responden } & \multirow{2}{*}{$\%$} & \multirow{2}{*}{ Kategori } \\
\hline & & 1 & 2 & 3 & 4 & & \\
\hline \multirow[b]{2}{*}{1} & $\begin{array}{l}\text { Alat peraga papan jam analog dapat memudahkan } \\
\text { siswa untuk memahami materi pengukuran sudut }\end{array}$ & 5 & 4 & 4 & 5 & 90 & Baik sekali \\
\hline & $\begin{array}{l}\text { Alat peraga papan jam analog memberi kemudahan } \\
\text { dan kejelasan dari siswa untuk menghitung } \\
\text { persoalan Matematika materi jam sudut }\end{array}$ & 5 & 4 & 4 & 5 & 90 & Baik sekali \\
\hline \multirow[b]{2}{*}{2.} & $\begin{array}{l}\text { Alat peraga papan jam analog dapat mendorong } \\
\text { siswa aktif mengikuti pembelajaran }\end{array}$ & 4 & 5 & 5 & 5 & 95 & Baik sekali \\
\hline & $\begin{array}{l}\text { Alat peraga papan jam analog dapat mendorong } \\
\text { siswa untuk aktif dalam kegiatan pengamatan dan } \\
\text { percobaan }\end{array}$ & 4 & 4 & 4 & 5 & 85 & Baik sekali \\
\hline \multirow{2}{*}{3.} & $\begin{array}{l}\text { Alat peraga papan jam analog dapat menciptakan } \\
\text { pembelajaran yang menyenangkan bagi siswa }\end{array}$ & 5 & 5 & 5 & 5 & 100 & Baik sekali \\
\hline & $\begin{array}{l}\text { Alat peraga papan jam analog dapat meningkatkan } \\
\text { semangat belajar siswa }\end{array}$ & 4 & 4 & 4 & 5 & 85 & Baik sekali \\
\hline \multirow[t]{2}{*}{4.} & $\begin{array}{l}\text { Desain alat peraga papan jam analog terlihat } \\
\text { menarik menurut siswa untuk belajar }\end{array}$ & 5 & 5 & 5 & 5 & 100 & Baik sekali \\
\hline & Tampilan warna alat peraga menarik & 4 & 4 & 4 & 5 & 85 & Baik sekali \\
\hline \multirow{3}{*}{5.} & $\begin{array}{l}\text { Alat peraga papan jam analog dapat meningkatkan } \\
\text { konsentrasi belajar siswa }\end{array}$ & 4 & 4 & 5 & 5 & 90 & Baik sekali \\
\hline & $\begin{array}{l}\text { Dari segi kekuatan (Tidak mudah patah, lepas, } \\
\text { berubah bentuk atau hancur ) bila digunakan }\end{array}$ & 4 & 4 & 4 & 5 & 85 & Baik sekali \\
\hline & Total & 44 & 43 & 44 & 50 & 90 & Baik sekali \\
\hline
\end{tabular}

Angket tanggapan juga diberikan kepada peserta didik untuk mengetahui manfaat produk alat peraga papan jam analog yang digunakan dalam proses belajar matematika. Angket produk 
dikembangkan berdasarkan karateristik alat peraga papan jam analog. Tanggapan siswa dapat dilihat pada Tabel 4.

Tabel 4. Tanggapan Siswa Kelas IV terhadap Alat Peraga Papan Jam Analog

\begin{tabular}{|c|c|c|c|c|c|c|c|c|c|}
\hline \multirow{2}{*}{ No. } & \multirow{2}{*}{ Pertanyaan } & \multicolumn{6}{|c|}{ Jumlah Responden } & \multirow{2}{*}{$\%$} & \multirow{2}{*}{ Kategori } \\
\hline & & 1 & 2 & 3 & 4 & 5 & 6 & & \\
\hline 1 & Saya suka belajar dengan & 1 & 1 & 1 & 1 & 1 & 1 & 100 & Baik sekali \\
\hline 2. & $\begin{array}{l}\text { Menurut saya alat peraga papan jam analog } \\
\text { sulit untuk di pahami }\end{array}$ & 1 & 1 & 1 & 1 & 1 & 1 & 100 & Baik sekali \\
\hline 3. & $\begin{array}{l}\text { Menurut saya membedakan macam- macam } \\
\text { sudut dengan alat peraga papan jam analog } \\
\text { sangat mudah }\end{array}$ & 1 & 1 & 1 & 1 & 1 & 1 & 100 & Baik sekali \\
\hline 4. & $\begin{array}{l}\text { Menurut saya bentuk alat peraga papan jam } \\
\text { analog bulat sangat menarik }\end{array}$ & 1 & 1 & 1 & 1 & 1 & 1 & 100 & Baik sekali \\
\hline 5. & $\begin{array}{l}\text { Saya lebih mudah memahami apa yang } \\
\text { disampaikan guru dengan menggunakan alat } \\
\text { peraga papan jam analog }\end{array}$ & 1 & 1 & 1 & 1 & 1 & 1 & 100 & Baik sekali \\
\hline 6. & $\begin{array}{l}\text { Saya belum pernah menemukan alat peraga } \\
\text { yang digunakan oleh guru matematika pada saat } \\
\text { pembelajaran }\end{array}$ & 1 & 1 & 1 & 1 & 1 & 1 & 100 & Baik sekali \\
\hline 7. & $\begin{array}{l}\text { Bahan yang digunakan untuk membuat alat } \\
\text { peraga papan jam analog mudah di dapat dari } \\
\text { lingkungan sekitar }\end{array}$ & 1 & 1 & 1 & 1 & 1 & 1 & 100 & Baik sekali \\
\hline 8. & $\begin{array}{l}\text { Penggunaan alat peraga papan jam analog dapat } \\
\text { membantu saya menemukan kesalahan sendiri } \\
\text { pada saat mengerjakan soal- soal latihan }\end{array}$ & 1 & 1 & 1 & 1 & 1 & 1 & 100 & Baik sekali \\
\hline 9. & $\begin{array}{l}\text { Alat peraga papan jam analog memiliki ukuran } \\
\text { yang sesuai }\end{array}$ & 1 & 1 & 1 & 1 & 1 & 1 & 100 & Baik sekali \\
\hline 10. & $\begin{array}{l}\text { Guru menjelaskan materi pengukuran sudut } \\
\text { dengan lancar menggunakan alat peraga papan } \\
\text { jam analog }\end{array}$ & 1 & 1 & 1 & 1 & 1 & 1 & 100 & Baik sekali \\
\hline & Total & 10 & 10 & 10 & 10 & 10 & 10 & 100 & Baik sekali \\
\hline
\end{tabular}

Dari Tabel 4 dapat diketahui bahwa tanggapan peserta didik kelas IV terhadap alat peraga papan jam analog secara keseluruhan dalam kategori "Baik Sekali".

\section{Efektifitas Pembelajaran}

Implementasi alat peraga papan jam analog dalam proses pembelajaran tidak membutuhkan waktu yang lama. Peserta didik terlebih dahulu dipahamkan bagian-bagian dan fungsi yang ada pada alat peraga papan jam analog. Setelah peserta didik paham dengan penggunaan papan jam analog, maka peserta didik diajak untuk memperagakan alat peraga papan jam analog di depan kelas dengan contoh soal yang disiapkan. Efektifitas produk alat peraga papan jam analog dalam penelitian ini diukur dengan tes akhir (post-test) yang berisi 20 item soal pilihan ganda yang diberikan kepada peserta didik baik pada kelas kontrol maupun kelas eksperimen. Peserta didik yang mengikuti post-test sebanyak 56 anak terbagi menjadi 2 kelas yaitu kelas kontrol sebanyak 31 dan kelas eksperimen sebanyak 25 peserta didik. Dari hasil analisis data, dinyatakan data berdistribusi normal sebagaimana terlihat pada Tabel 5 . 
EDUMATIKA: Jurnal Riset Pendidikan Matematika

Tabel 5. Hasil Uji Normaliatas

\begin{tabular}{ccccc}
\hline Kelas & $\boldsymbol{x}_{\text {hitung }}^{2}$ & Dk & $\boldsymbol{x}_{\text {tabel }}^{2}$ & Ketrangan \\
\hline Eksperimen & 5,65101 & 5 & 11,07 & Normal \\
\hline Kontrol & 9,72629 & 5 & 11,07 & Normal \\
\hline
\end{tabular}

Dari hasil perhitungan homogenitas sampel, disimpulkan bahwa kedua data bervarian homogen. Hasil analisis dapat dilihat pada Tabel 6.

Tabel 6. Hasil Uji Homogenitas

\begin{tabular}{ccccc}
\hline No. & Kelas & $\boldsymbol{F}_{\text {hitung }}$ & $\boldsymbol{F}_{\text {tabel }}$ & Kriteria \\
\hline 1. & IV D & \multirow{2}{*}{1,2935} & 2,1358 & \multirow{2}{*}{ Homogen } \\
\hline 2. & IV B & & \\
\hline
\end{tabular}

Setelah diketahui kelas eksperimen dan kelas kontrol merupakan kelas yang berdistribusi normal dan memiliki varians homogen, selanjutnya melakukan uji kesamaan rata-rata atau uji-t dua pihak untuk menegetahui apakah kedua kelas tersebut memiliki rata-rata yang sama. Hasil uji-t dua pihak tersaji pada Tabel 7.

Tabel 7. Hasil Uji-t

\begin{tabular}{ccc}
\hline Aspek & $\boldsymbol{t}_{\text {hitung }}$ & $\boldsymbol{t}_{\text {tabel }}$ \\
\hline Hasil belajar & 2,33 & 2,063 \\
\hline
\end{tabular}

Berdasarkan Tabel 4, dapat disimpulkan bahwa nilai rata- rata hasil belajar peserta didik pada materi pengukuran sudut dengan menggunakan alat peraga papan jam analog pada kelas eksperimen lebih tinggi dari pada rata-rata nilai pembelajaran tanpa menggunakan alat peraga papan jam analog. Hal ini juga dapat dilihat dari perbedaan rata-rata hasil belajar kelas eksperimen dan kelas kontrol. Rerata hasil belajar kelas kontrol $\bar{x}_{1}=47,4$ sedangkan rata- rata kelas eksperimen $\bar{x}_{2}=76,4$. Penelitian ini juga berhasil menjadikan minat peserta didik lebih terbangun dengan baik untuk mengikuti kegiatan pembelajaran matematika. Perhatian peserta didik untuk belajar dan pemahaman peserta didik pada materi pelajaran jauh lebih baik daripada peserta didik di kelas kontrol. Dengan kata lain, penggunaan alat peraga jam sudut berpengaruh terhadap hasil belajar matematika peserta didik.

\section{KESIMPULAN}

Berdasarkan analisis validasi produk pengembangan media pembelajaran edukatif berupa alat peraga papan jam analog pada pembelajaran matematika materi pengukuran sudut di kelas IV MI Nashrul Fajar layak untuk digunakan pada pembelajaran matematika materi pengukuran sudut. Selain itu, papan jam analog juga efektif digunakan untuk membantu peserta didik dalam memahami materi pengukuran sudut kelas IV yang dibuktikan dengan meningkatnya hasil belajar khususnya pada ranah kognitif. 


\section{UCAPAN TERIMA KASIH}

Penulis mengucapkan terima kasih kepada Madrasah Ibtidaiyah Nashrul Fajar Semarang selaku lembaga mitra yang telah memberikan izin untuk berkontribusi dalam menyelesaikan masalah pembelajaran matematika materi sudut; dekan Fakultas Agama Islam Universitas Wahid Hasyim selaku pimpinan yang telah mendukung dilakukannya penelitian ini; dan Lembaga Penelitian dan Pengabdian Masyarakat (LPPM) Universitas Wahid Hasyim sebagai penyandang dana sehingga penelitian ini dapat diselesaikan.

\section{DAFTAR RUJUKAN}

Ahdhianto, E. (2016). Pengembangan Modul Pembelajaran Geometri Bangun Datar Berbasis Teori Van Hiele untuk Siswa Kelas VI Sekolah Dasar. Jurnal Pendidikan Dasar Nusantara, 1(2), 37-48.

Andrianto, R. (2017). Pengembangan Alat Peraga Edukatif Mistar Bilangan Bulat (Misbilbul) Mata Pelajaran Matematika Untuk Kelas IV SDN Golo. E-Jurnal Skripsi Program Studi Teknologi Pendidikan, 6(6), 536-544.

Ariyanto, L., Aditya, D., \& Dwijayanti, I. (2019). Pengembangan Android Apps Berbasis Discovery Learning untuk Meningkatkan Pemahaman Konsep Matematis Siswa Kelas VII. Edumatika: Jurnal Riset Pendidikan Matematika, 2(1), 40. https://doi.org/10.32939/ejrpm.v2i1.355

Betyka, F., Putra, A., \& Erita, S. (2019). Pengembangan Lembar Aktivitas Siswa Berbasis Penemuan Terbimbing pada Materi Segitiga. JURING (Journal for Research in Mathematics Learning), 2(2), 179-189.

Junaedi, I., \& Asikin, M. (2012). Pengembangan Pembelajaran Matematika Humanistik untuk Meningkatkan Kemahiran Matematis. Unnes Journal of Research Mathematics Education, 1(2).

Lukman, H. S., \& Setiani, A. (2018). Validitas Bahan Ajar Statistika Terapan Berbasis ICT Terintegrasi Proyek. Edumatika: Jurnal Riset Pendidikan Matematika, 1(2), 36-46.

Malasari, N., \& Hakim, A. R. (2017). Pengembangan Media Belajar pada Operasi Hitung untuk Tingkat Sekolah Dasar. JKPM (Jurnal Kajian Pendidikan Matematika), 3(1), 11. https://doi.org/10.30998/jkpm.v3i1.1911

Mariyana, F. A., Rosady, I. A., \& Latifah, N. (2018). Pemahaman Konsep Melalui Pendekatan Pendidikan Matematika Realistik Indonesia pada Materi Pengukuran Sudut di Kelas IV Sekolah Dasar. Sekolah Dasar: Kajian Teori Dan Praktik Pendidikan, 27(2), 98-107. https://doi.org/10.17977/um009v27i22018p098

Murdiyanto, T., \& Mahatama, Y. (2014). Pengembangan Alat Peraga Matematika Untuk Meningkatkan Minat Dan Motivasi Belajar Matematika Siswa Sekolah Dasar. Sarwahita, 11(1), 38. https://doi.org/10.21009/sarwahita.111.07

Nugrahanta, G. A., Rismiati, C., Anugrahana, A., \& Kurniastuti, I. (2016). Berbasis Metode Montessori Papan Dakon Operasi Bilangan Bulat untuk Siswa SD. Jurnal Penelitan (Edisi Khusus PGSD), 20(2), 103-116.

Nurmutiatun. (2018). Pengembangan Alat Peraga Garis Satuan Panjang pada Siswa Kelas IV SD Negeri I Kutoarjo. EKUIVALEN-Pendidikan Matematika, 31(1), 19-24.

Prasetyo, E. (2015). Ternyata Penelitian Itu Mudah (Panduan Pelaksanaan Bidang Pendidikan). Lumajang: Edunomi.

Putra, A., Ulandari, N., \& Sepnila, D. (2020). Penerapan Model Pembelajaran Quick on The Draw dengan Masalah Open-Ended terhadap Pemahaman Konsep Matematis Siswa. Jurnal Pendidikan Matematika Raflesia, 5(1), 1-16.

Setyosari, P. (2016). Metode Penelitian Pendidikan dan Pengembangan. Jakarta: Prenada Media Group. 
EDUMATIKA: Jurnal Riset Pendidikan Matematika

Sugiyono. (2017). Metode Penelitian Dan Pengembangan. Bandung: Alfabeta.

Sugiyono. (2016). Metode Penelitian Pendidikan Pendekatan Kuantitatif, Kualitatif, dan R\&D. Bandung: Alfabeta.

Trianto. (2010). Mendesain Model Pembelajaran Inovatif-Progresif. Jakarta: Kencana Prenada Media Group.

Widyawati, W., Putri, R. I. I., \& Somakim, U. (2016). Desain Pembelajaran Sudut Menggunakan Konteks Rumah Limas di Kelas VII. JINoP (Jurnal Inovasi Pembelajaran), 2(2), 437-448. https://doi.org/10.22219/jinop.v2i2.3489 